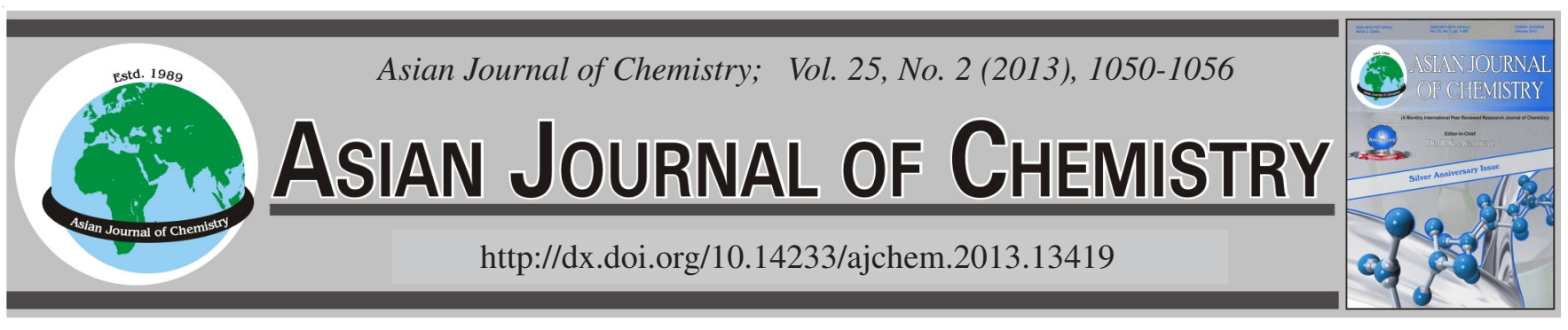

\title{
Two Flavan Derivatives Isolated from Artocarpus dadah Grown in Lampung, Indonesia
}

\author{
Tati Suhartati ${ }^{1, *}$, YANDRI $^{1}$, JHONS F. Suwandi $^{2}$ and Sutopo Hadi ${ }^{1}$
}

\begin{abstract}
${ }^{1}$ Department of Chemistry, Faculty of Mathematics and Natural Sciences, University of Lampung, Bandar Lampung 35145, Indonesia ${ }^{2}$ Faculty of Medicine, University of Lampung, Bandar Lampung 35145, Indonesia
\end{abstract}

*Corresponding author: E-mail: tatisuhartati@unila.ac.id; sutopohadi@unila.ac.id

(Received: 10 January 2012;

Accepted: 30 August 2012)

AJC-12041

From the root bark of Artocarpus dadah grown in Lampung, Indonesia have successfully been isolated two flavan derivatives, afzelecin-
3-O- $\alpha$-L-ramnoside and chatecin. The structure of both compounds were determined based on physical properties and UV-VIS, IR and
NMR spectroscopies.
Key Words: Lampung, Afzelecin-3-O- $\alpha$-L-ramnoside, Chatecin.

\section{INTRODUCTION}

We have reported that from the root skin of $A$. dadah has been isolated morusin, a flavonoid compound, which showed high activity against murine leukemia cancer cell, P-388 with $\mathrm{IC}_{50}$ value of $3.1 \mu \mathrm{g} / \mathrm{mL}^{1}$. Furthermore from the root wood of A. dadah, oxyresveratrol has also succesfully been isolated which showed high activity on cytotoxicity test against murine leukemia cancer cell, P-388 as well as in vitro and in vivo antimalarial test $\mathrm{t}^{2,3}$.

In this paper we reported the isolation and structural determination of two compounds of flavan derivatives from root bark of $A$. dadah, afzelecin-3-O- $\alpha$-L-ramnoside (1) and chatecin (2) based on physical properties and spectroscopies of UV-VIS, IR and $1 \mathrm{D}$ and $2 \mathrm{D}$ of ${ }^{1} \mathrm{H}-$ and ${ }^{13} \mathrm{C}$ NMR. However, these two compounds did not showed good activity in cytotoxicity test against murine leukemia cancer cell, P-388.

\section{EXPERIMENTAL}

Thin layer chromatography analysis was carried out on pre-coated Si-gel plates (Merck Kieselgel 60 F254, 0.25 mm) and the UV lamp of Spectroline, ENF-240 C/F Model was used to see the spot in thin layer chromatography. VLC was carried out using Merck Si-gel 60. Melting points were determined on a Fisher Johns micro-melting point apparatus and are uncorrected. UV-VIS and IR spectra were measured with Beckman DU-7000 and Varian 2000 FTIR spectrophotometers respectively. ${ }^{1} \mathrm{H}$ NMR spectrum was recorded with a JEOL ECA 500 spectrometer, operating at $500.00 \mathrm{MHz},{ }^{13} \mathrm{C}$ NMR NMR spectrum was recorded with a JEOL ECA 500 spectrometer, operating at $125.00 \mathrm{MHz}$; DEPT-135, HMQC and HMBC spectra were also recorded with a JEOL ECA 500 spectrometer.
The samples of root bark of A. dadah were collected from Purwoasri Village, North Metro, Lampung. The plant was identified by the staff at the Herbarium Bogoriense, Research Centre for Biology, Indonesia Institute of Sciences Bogor, Indonesia and a voucher specimen has been deposited at the herbarium.

Extraction and isolation: $2.4 \mathrm{~kg}$ of root bark powdered of A. dadah was macerated for $24 \mathrm{~h}$ with $18 \mathrm{~L}$ methanol, in every maceration $200 \mathrm{~g}$ of samples was used and was perfor-med 3 times. The methanol extract was filtered off then evaporated with vacuum rotary evaporator at $45-50{ }^{\circ} \mathrm{C}$ with rotation rate of 120-150 rpm. The concentrated extract of methanol was added with $\mathrm{NaCl} 1 \%$ by $20 \%$ volume based on the methanol extract and then partitioned with dichloromethaneethyl acetate $20 \%$. The partition result was evaporated with vacuum rotary evaporator at $30-40{ }^{\circ} \mathrm{C}$ with rotation rate of $120-150 \mathrm{rpm}$ and the extract obtained was $151.28 \mathrm{~g}$. The extract was partitioned by vacuum liquid chromatography with adsorbent of silica gel using eluent of methanol/dichloromethane by increasing the eluent polarity from $0-100 \%$. Based on the chromatogram obtained by thin layer chromatography, there were 4 main fractions, A-D fractions. B fraction (2.1675 g) and $\mathrm{C}$ fraction ( $47 \mathrm{~g}$ ) were further fracinated with VLC using eluent of EtOAc/hexane. $\mathrm{C}$ fraction produced 8 fractions (C $1-8)$.

After few steps of VLC, column chromatography and flash chromatography using eluent of n-hexane, dichloromethane and EtOAc with variety of concentrations, the fractions with the same $\mathrm{R}_{\mathrm{f}}$ on thin layer chromatography from main fraction $\mathrm{B}$ and result of fractionation $\mathrm{C}(\mathrm{C} 1)$ were combined and further purified using column chromatography and flash chromatography. 


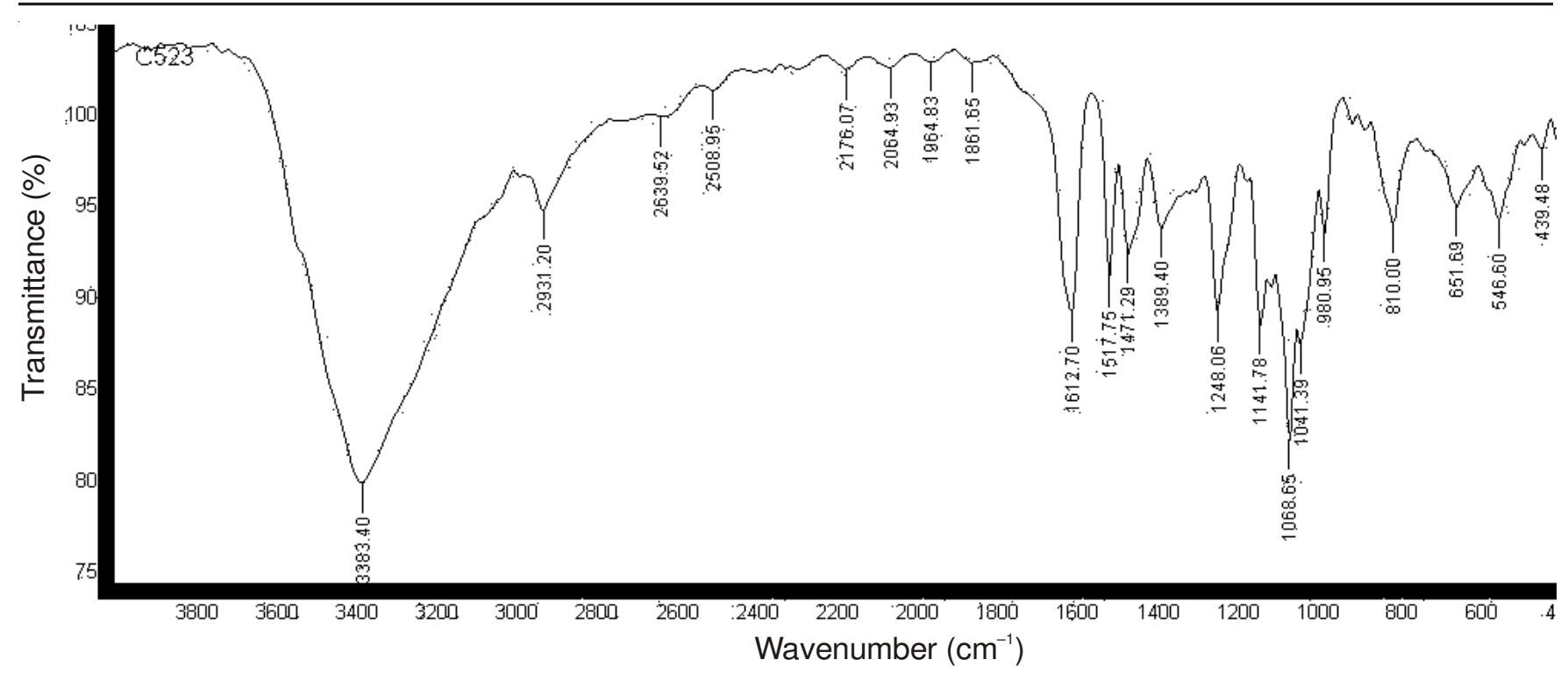

Fig. 1. IR Spectrum of compound 1

From this combined fractions, yellow brown crystal was obtained and it was known as morusin², 25 mg, m.p. 118-123 ${ }^{\circ} \mathrm{C}$ (crystallized in dichloromethane- $n$-hexane). From C5 fraction, after few steps of chromatography was obtained compound 1, white amorphous crystal 14.6 g, m.p. $162-167^{\circ} \mathrm{C}$ (crystallized in EtOAc- $n$-hexane). The thin layer chromatography analysis of compound $\mathbf{1}$ showed one spot with $\mathrm{R}_{\mathrm{f}}$ of 0.25 using eluent of acetone/dichloromethane $50 \%, \mathrm{R}_{\mathrm{f}} 0.48$ using eluent of acetone/EtOAc $20 \%$ and $\mathrm{R}_{\mathrm{f}} 0.58$ using eluent acetone/EtOAc $40 \%$.

By applying a different method, $1.5 \mathrm{~kg}$ of root bark sample was macerated with methanol/water $90 \% 3 \times 24 \mathrm{~h}$ and it was repeated 4 times. The filtrate was then evaporated with vacuum rotary evaporator to produce methanol extract. The methanol extract was partitioned using EtOAc and the result of the partitioned was evaporated again with vacuum rotary evaporator to produce EtOAc extract $25 \mathrm{~g}$. The EtOAc extract was partitioned with VLC using eluent of methanol/dichloromethane (0-20\%) and produced 10 main fractions. $2.75 \mathrm{~g}$ of fraction 8 was partitioned few times by chromatography and produced compound 2 as white amorphous cystral $10 \mathrm{mg}$, melting point $153-153^{\circ} \mathrm{C}$. The thin layer chromatography analysis of compound $\mathbf{2}$ using three eluent systems, one spot was obtained with $\mathrm{R}_{\mathrm{f}} 0.33$ using eluent EtOAc/ $n$-hexane $70 \%, \mathrm{R}_{\mathrm{f}} 0.53$ using eluent EtOAc/ dichloromethane $70 \%$ and $\mathrm{R}_{\mathrm{f}} 0.69$ using eluent EtOAc $100 \%$.

Structure determination: The structure of pure compound was determined based on physical data of melting point and spectroscopy techniques of UV-VIS, IR and NMR as well as test with some specific reagents.

Bioactivity test on the pure compound: The bioactivity test performed was cytotoxicity test of compound $\mathbf{1}$ and $\mathbf{2}$ based on the method of Alley et al. ${ }^{4}$.

\section{RESULTS AND DISCUSSION}

Spectrophotometry analysis of compound 1: The infrared spectrum of $\mathbf{1}$ (Fig. 1) showed that there is wide band in the region of $3500-3300 \mathrm{~cm}^{-1}$, which indicated the stretching vibration of hydroxyl group that can form hydrogen bond.
The absorption peak at $2931 \mathrm{~cm}^{-1}$ indicated the presence of C-H alipihatic. The peaks at 1612, 1517 and $1471 \mathrm{~cm}^{-1}$ were indication the presence of $\mathrm{C}=\mathrm{C}$ aromatic which was supported by the presence of C-H aromatic at $900-600 \mathrm{~cm}^{-1}$. The absorption peak at 1389 and $1248 \mathrm{~cm}^{-1}$ indicated the bond stretch of C-O from alcohol. Based on the IR data (Fig. 1) the compound $\mathbf{1}$ is predicted to have phenolic frame.

The UV-Vis spectrum of compound $\mathbf{1}$ is shown in Fig. 2. Based on this spectrum, there are maximum wavelength with $\lambda_{\max }$ of 274, 226 (shoulder) and $206 \mathrm{~nm}$ in metanol using concentration of $0.0001 \mathrm{~g} / 0.01 \mathrm{~L}(0.1 \mathrm{mg} / 10 \mathrm{~mL})$. By the addition of $\mathrm{NaOH}$, the was batochromic shift to longer $\lambda_{\max }$ 285, 244 and $209 \mathrm{~nm}$ were observed. This shift strengthen the theory that in compound $\mathbf{1}$ has unconjugated phenolic group ${ }^{5}$.

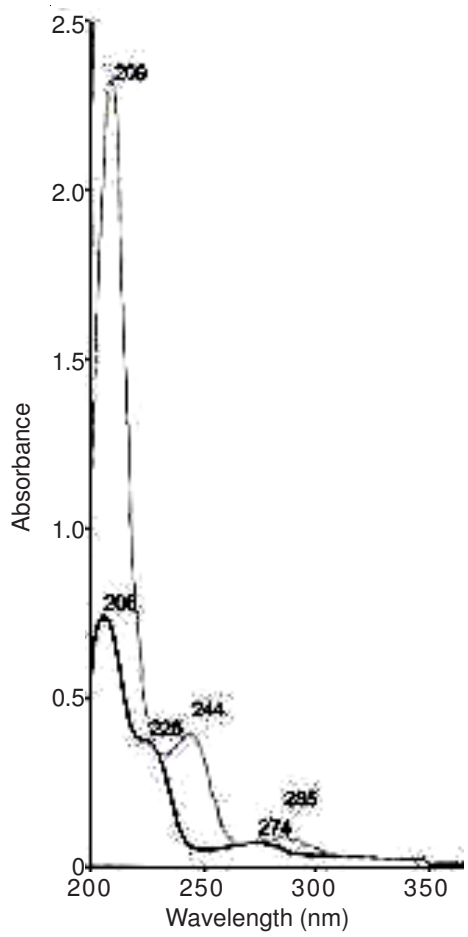

Fig. 2. UV spectrum of compound $\mathbf{1}$ (a) in $\mathrm{MeOH}$, (b) in $\mathrm{MeOH}+\mathrm{NaOH}$ 


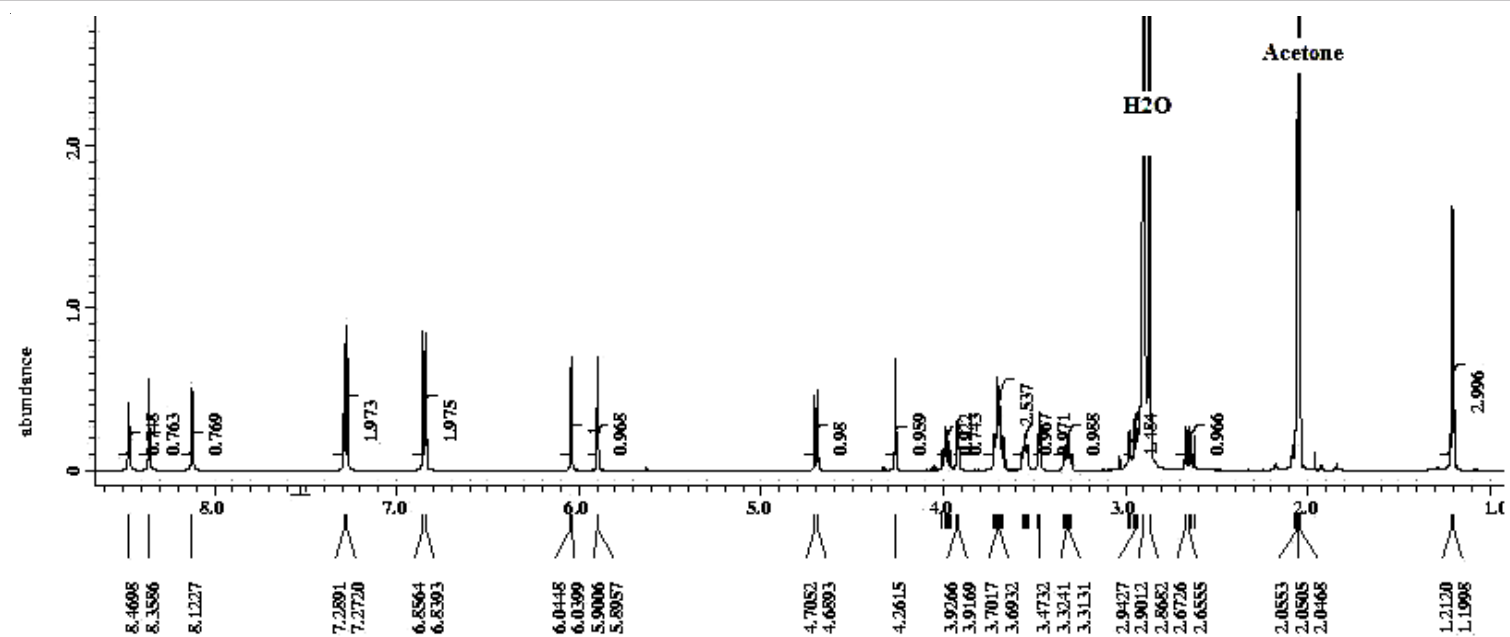

Fig. 3. ${ }^{1} \mathrm{H}$ NMR spectrum of compound $\mathbf{1}$

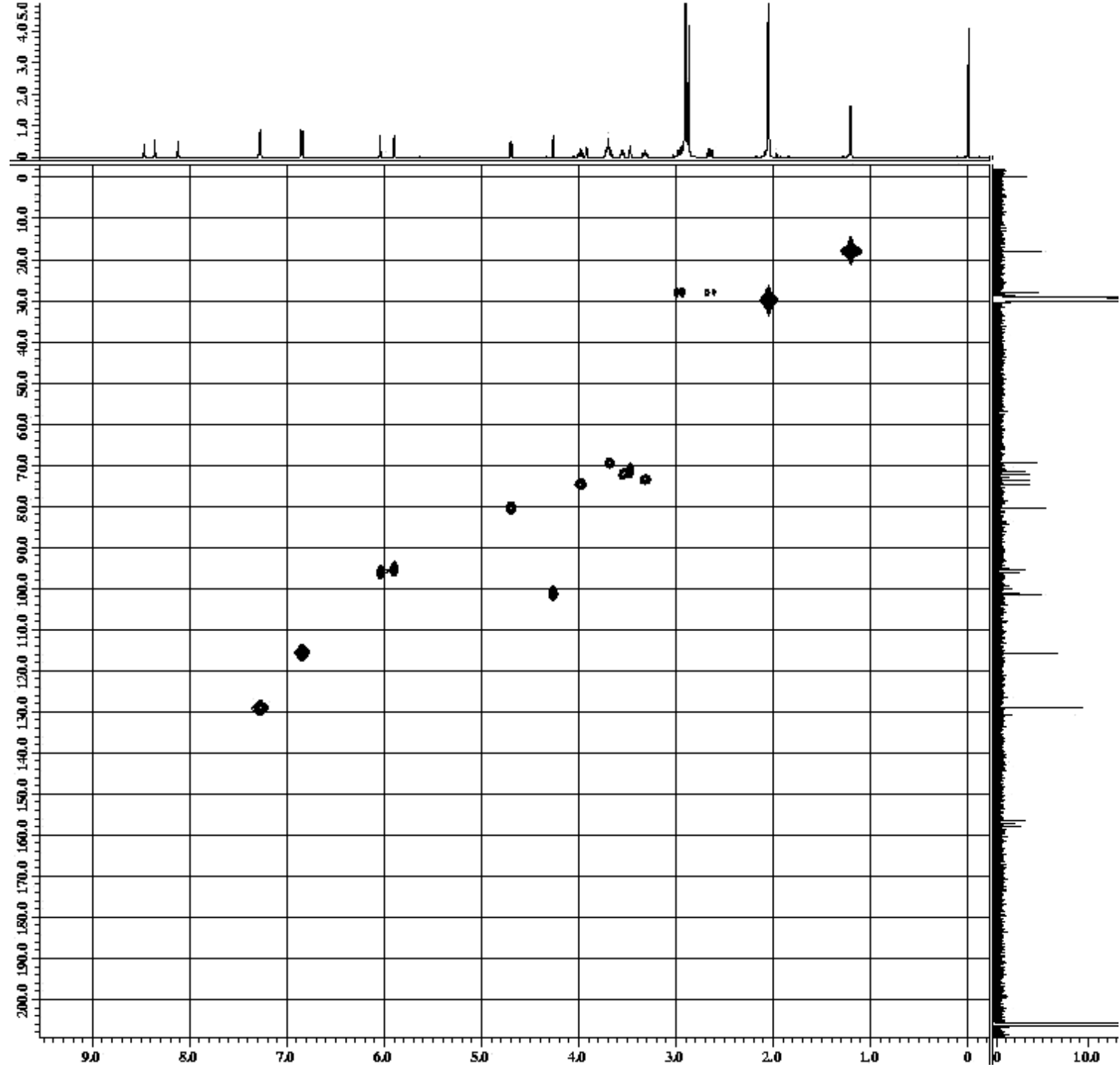

Fig. 4 HMQC spectrum compound 1

The ${ }^{1} \mathrm{H}$ NMR spectrum of $\mathbf{1}$ (Fig. 3 ) showed signals at $\delta$ (ppm): $5.90(1 \mathrm{H}, \mathrm{d}, J=2.5 \mathrm{~Hz}) ; 6.04(1 \mathrm{H}, \mathrm{d}, J=2.5 \mathrm{~Hz})$; $6.845(2 \mathrm{H}, \mathrm{d}, J=8.5 \mathrm{~Hz}) ; 7.275(1 \mathrm{H}, \mathrm{d}, J=8.5 \mathrm{~Hz})$ due to the aromatic protons. The proton signals of aromatic $\mathrm{OH}$ were observed as singlet at $8.12 ; 8.36$; and $8.47 \mathrm{ppm}$. The aliphatic proton signals were observed at $2.665(1 \mathrm{H}, \mathrm{q}, J=8.5$ and 18.5 $\mathrm{Hz}) ; 2.92(1 \mathrm{H}, \mathrm{q}, J=5.5 \mathrm{dan} 20 \mathrm{~Hz}) ; 3.92(1 \mathrm{H}, \mathrm{t}, J=4.85 \mathrm{~Hz})$; and $4.695(1 \mathrm{H}, \mathrm{d}, J=8.00 \mathrm{~Hz}) \mathrm{ppm}$. Using HMQC (Fig. 4) and dept with decouple (Fig. 5) data, the first two protons were bound to one methylene carbon, while two other protons of 

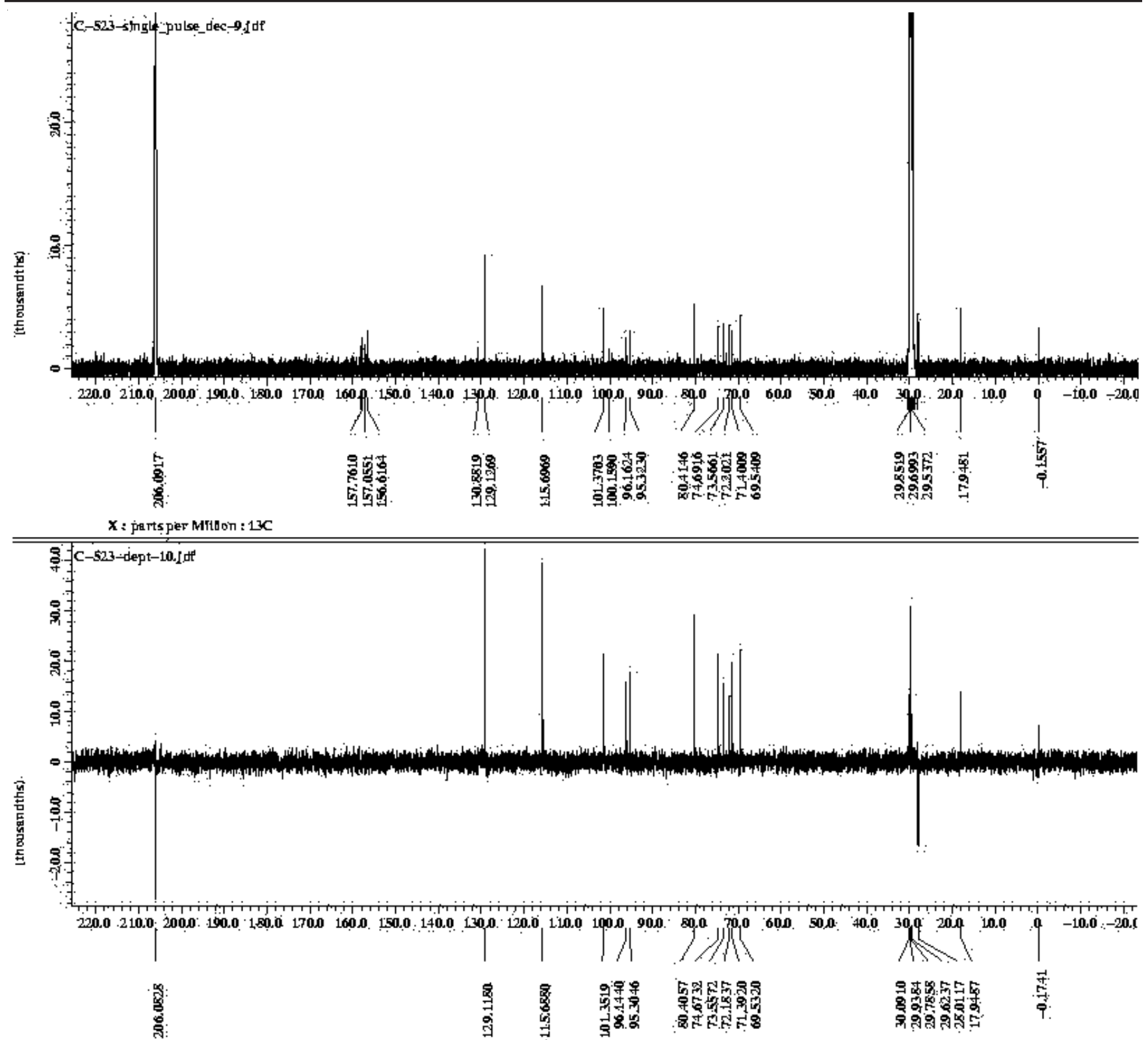

Fig. 5 DEPT-135 spectrum of compound 1

each methyne where the carbon is bound to oxygen indicated substituted pirane proton. The same methyne protons were also observed at $3.315(1 \mathrm{H}, \mathrm{m}) ; 3.47(1 \mathrm{H}, \mathrm{t}, J=8.5 \mathrm{~Hz}) ; 3.54$ $(1 \mathrm{H}, \mathrm{m}) ; 3.69(1 \mathrm{H}, \mathrm{m}) ; 4.26(1 \mathrm{H}, \mathrm{s}) \mathrm{ppm}$, one proton methyl signal was also observed at $1.20 \mathrm{ppm}(3 \mathrm{H}, \mathrm{d}, J=6.0 \mathrm{~Hz})$. This signal is perhaps due to the presence of one sugar group. Based on the DEPT spectrum, there were six carbon signals lost at $\delta$ (ppm) $158.02 ; 157.76 ; 157.06 ; 156.61 ; 130.88$; and 100.16 $\mathrm{ppm}$. The first four signals were from aromatic carbon substituted by oxygen, while the other two were from aromatic carbon substituted by carbon.

Based on the HMBC spectrum of 1 (Fig. 6) which showed the correlation of protons with carbon in the molecule resulted the deduction that compound $\mathbf{1}$ is afzelecin-3-O- $\alpha-\mathrm{L}-$ ramnoside. The data comparison of ${ }^{1} \mathrm{H}$ and ${ }^{13} \mathrm{C}$ NMR of 1 with data in the literature ${ }^{6}$ is shown in Table-1. Afzelecin-3-O- $\alpha$ L-ramnoside has also been found and previously reported by Su et al. ${ }^{7}$ from the stem and twig bark of A. dadah by Achmad et al. ${ }^{6}$ and from stem and root barks of A. reticulatus and (+)afzelecin 3-ramnoside by Drewes and Taylor ${ }^{8}$ from Cassipourea gerrardii.

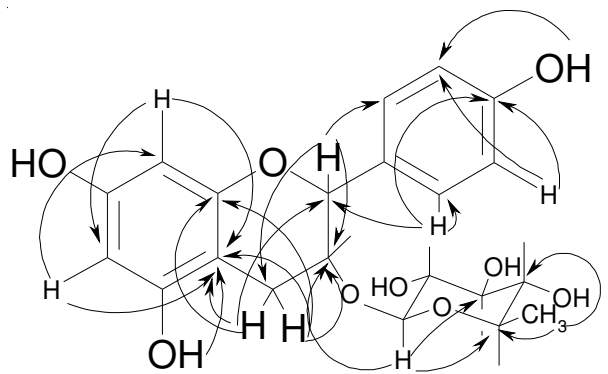

Fig. 6. Corelation of H-C from HMBC of compound $\mathbf{1}$

Spectrophotometry analysis of compound 2: The infrared spectrum of 2 (Fig. 7) showed that there is wide band in the region of $3500-3200 \mathrm{~cm}^{-1}$ which indicated the stretching vibration of hydroxyl group that can form hydrogen bond. 


\begin{tabular}{|c|c|c|c|c|}
\hline \multicolumn{5}{|c|}{$\begin{array}{c}\text { TABLE- } 1 \\
\text { THE COMPARISON OF }{ }^{1} \mathrm{H}-\text { AND }{ }^{13} \mathrm{C}-\mathrm{NMR} \text { DATA OF COMPO }\end{array}$} \\
\hline \multicolumn{2}{|c|}{ 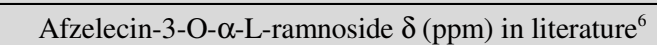 } & \multirow[t]{2}{*}{$\mathrm{C}$} & \multicolumn{2}{|c|}{ Compound 1 (acetone $\left.\mathrm{d}_{6}\right) \delta(\mathrm{ppm})$} \\
\hline${ }^{1} \mathrm{H}-\mathrm{NMR}$ & ${ }^{13} \mathrm{C}-\mathrm{NMR}$ & & ${ }^{1} \mathrm{H}-\mathrm{NMR}$ & ${ }^{13} \mathrm{C}-\mathrm{NMR}$ \\
\hline $4.65(1 \mathrm{H}$. d. $J=8.1 ; 16.1 \mathrm{~Hz})$ & 81.14 & 2 & 4.695 (1H. m) & 80.41 \\
\hline $3.92(1 \mathrm{H}$. ddd. $J=5.9 ; 7.4 ; 8.5 \mathrm{~Hz})$ & 76.20 & 3 & $3.92(1 \mathrm{H}$. d. $J=4.85 \mathrm{~Hz})$ & 74.69 \\
\hline $2.63(1 \mathrm{H}$. dd. $J=8.5 ; 16.1 \mathrm{~Hz})$ & 28.26 & 4 & $2.665(1 \mathrm{H}$. dd. $J=8.5 ; 18.5 \mathrm{~Hz})$ & 28.03 \\
\hline \multirow[t]{3}{*}{$2.90(1 \mathrm{H}$. dd. $J=5.9 ; 16.1 \mathrm{~Hz})$} & & & $2.92(1 \mathrm{H}$. dd. $J=5.50 ; 20.0 \mathrm{~Hz})$ & \\
\hline & 100.68 & $4 a$ & & 100.16 \\
\hline & 157.57 & 5 & & 157.06 \\
\hline \multirow[t]{2}{*}{$5.93(1 \mathrm{H}$. d. $J=2.5 \mathrm{~Hz})$} & 96.38 & 6 & $6.04(1 \mathrm{H} . \mathrm{d} . J=2.5 \mathrm{~Hz})$ & 96.16 \\
\hline & 157.97 & 7 & & 157.76 \\
\hline \multirow[t]{3}{*}{$5.85(1 \mathrm{H}$. d. $J=2.4 \mathrm{~Hz})$} & 95.45 & 8 & $5.90(1 \mathrm{H} . \mathrm{d} . J=2.5 \mathrm{~Hz})$ & 95.32 \\
\hline & 156.92 & $8 \mathrm{a}$ & & 156.62 \\
\hline & 131.22 & $i^{\prime}$ & & 130.88 \\
\hline $7.21(1 \mathrm{H} . t \mathrm{tt} . J=1.7 ; 2.8 ; 8.9 \mathrm{~Hz})$ & 129.40 & 2 & $7.28(1$ H.d. $J=8.5 \mathrm{~Hz})$ & 129.13 \\
\hline \multirow[t]{2}{*}{$6.78(1 \mathrm{H} . \mathrm{tt} . J=2.0 ; 2.8 ; 8.9 \mathrm{~Hz})$} & 116.07 & 3 & $6.845(1 \mathrm{H}$. d. $J=8.5 \mathrm{~Hz})$ & 115.70 \\
\hline & 158.53 & 4 & & 158.02 \\
\hline $6.78(1 \mathrm{H} . \mathrm{tt} . J=2.0 ; 2.8 ; 8.9 \mathrm{~Hz})$ & 116.07 & 5 & $6.845(1 \mathrm{H} . \mathrm{d} . J=8.5 \mathrm{~Hz})$ & 115.70 \\
\hline $7.21(1 \mathrm{H} . t \mathrm{tt} . J=1.7 ; 2.8 ; 8.9 \mathrm{~Hz})$ & 129.4 & 6 & 7.28 (1H.d. $J=8.5 \mathrm{~Hz})$ & 129.40 \\
\hline $4.24(1 \mathrm{H}$. d. $J=1.8 \mathrm{~Hz})$ & 102.26 & $1 "$ & $4.26(1 \mathrm{H} . \mathrm{s})$ & 101.37 \\
\hline $3.47(1 \mathrm{H} . \mathrm{dd} . J=1.7 ; 3.1 \mathrm{~Hz})$ & 71.97 & $2 "$ & $3.47(1 \mathrm{H} . \mathrm{t} . J=8.5 \mathrm{~Hz})$ & 71.40 \\
\hline $3.56(1 \mathrm{H} . \mathrm{dd} . J=3.4 ; 9.5 \mathrm{~Hz})$ & 72.24 & $3 "$ & 3.54 (1H. m) & 72.2 \\
\hline $3.30(1 \mathrm{H} . \mathrm{dd} . J=3.4 ; 9.5 \mathrm{~Hz})$ & 73.93 & $4 "$ & 3.315 (1H. m) & 73.57 \\
\hline $3.69(1$ H. m) & 70.32 & $5 "$ & $3.69(1 \mathrm{H} . \mathrm{m})$ & 69.54 \\
\hline $1.23(3 \mathrm{H}$. d. $J=6.1 \mathrm{~Hz})$ & 17.91 & $6 "$ & $1.20(3 \mathrm{H}$. d. $J=6.0 \mathrm{~Hz})$ & 17.95 \\
\hline
\end{tabular}

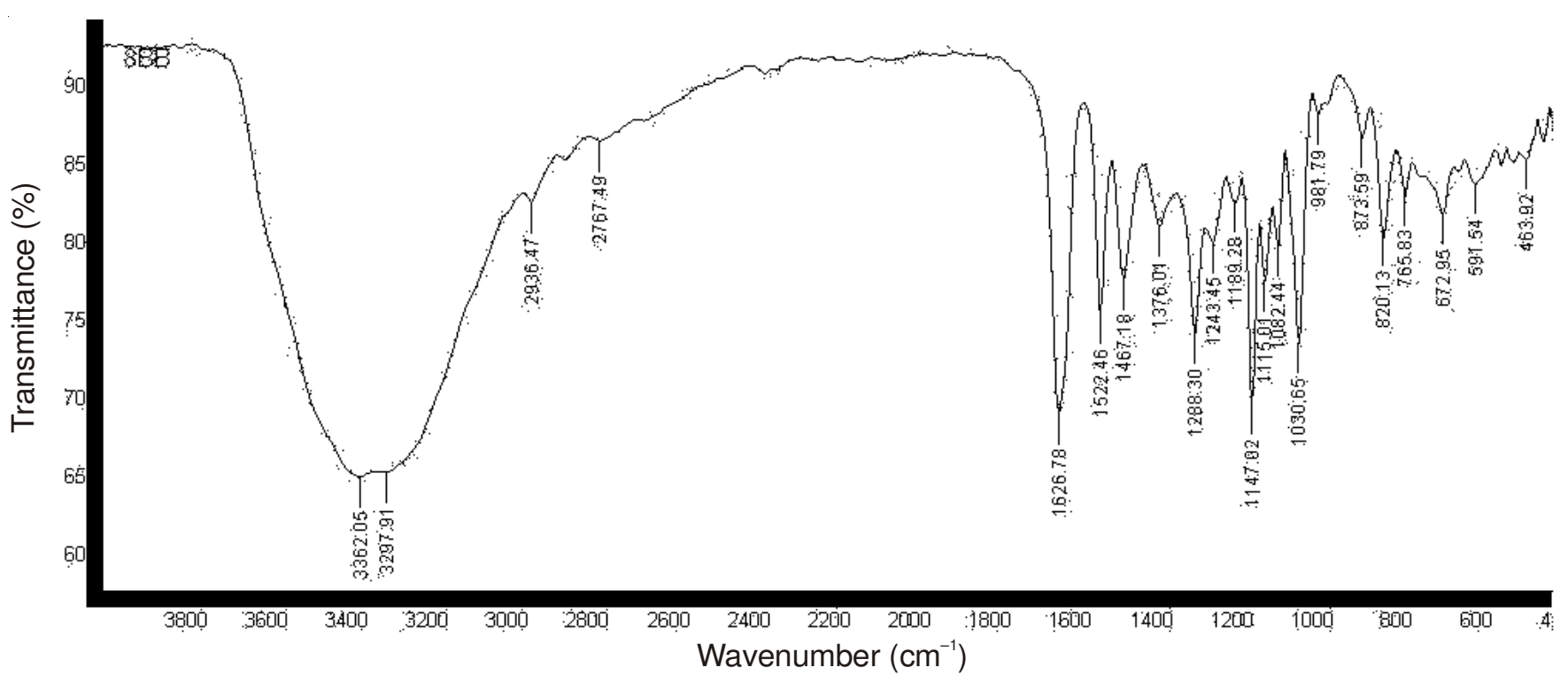

Fig. 7 IR spectrum of compound 2

The absorption peak at $2936 \mathrm{~cm}^{-1}$ and $2767 \mathrm{~cm}^{-1}$ indicated the presence of $\mathrm{C}-\mathrm{H}$ alipihatic. The peaks at 1626, 1522 and $1467 \mathrm{~cm}^{-1}$ were indication the presence of $\mathrm{C}=\mathrm{C}$ aromatic which was supported by the presence of $\mathrm{C}-\mathrm{H}$ aromatic at 900-600 $\mathrm{cm}^{-1}$. The absorption peak at 1376,1288 and $1243 \mathrm{~cm}^{-1}$ indicated the bond stretching of $\mathrm{C}-\mathrm{O}$ from alcohol. Based on the IR data in Fig. 7 the compound $\mathbf{2}$ is predicted to have phenolic frame.

Based on the UV-VIS spectrum of compound 2 (Fig. 8), there are maximum wavelenght with max at 280, 229 (shoulder) and $205 \mathrm{~nm}$ in methanol with concentration of $0.0001 \mathrm{~g} / 0.01$
$\mathrm{L}(0.1 \mathrm{mg} / 10 \mathrm{~mL})$. In addition with $\mathrm{NaOH}$, there was batochromic shift to longer maks 290, 243 and $208 \mathrm{~nm}$. This shift strengthen the theory that in compound $\mathbf{2}$ has unconjugated phenolic group 5 .

The ${ }^{1} \mathrm{H}$ NMR spectrum of 1 (Fig. 9) shown signals at $\delta$ (ppm): $5.96(1 \mathrm{H}, \mathrm{d}, J=1.85 \mathrm{~Hz}) ; 5.815(1 \mathrm{H}, \mathrm{d}, J=2.45 \mathrm{~Hz})$; $6.83(1 \mathrm{H}, \mathrm{d}, J=1.85 \mathrm{~Hz}) ; 6.73(1 \mathrm{H}, \mathrm{d}, J=8.6 \mathrm{~Hz}) ; 6.70(1 \mathrm{H}$, $\mathrm{d}, J=1.8 ; 7.95 \mathrm{~Hz}$ ) due to the aromatic protons. The proton signals of aromatic $\mathrm{OH}$ were observed as singlet at $8.15 ; 7.96$; and $7.85 \mathrm{ppm}$. The aliphatic proton signals were observed at $2.465(1 \mathrm{H}, \mathrm{dd}, J=8.5 ; 16.12 \mathrm{~Hz}) ; 3.92(2 \mathrm{H}, \mathrm{m}) ; 4.50(1 \mathrm{H}, \mathrm{d}$, 


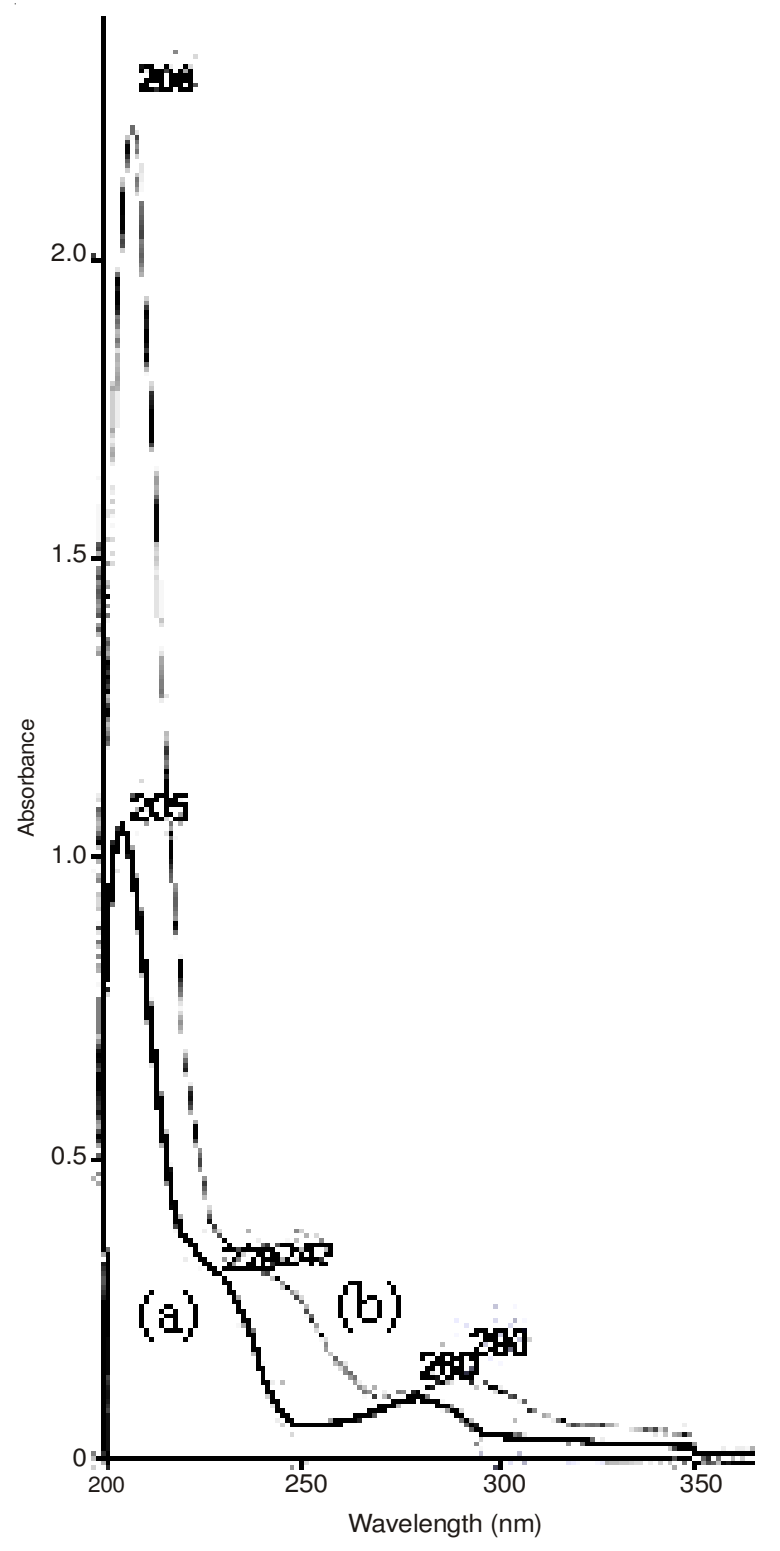

Fig. 8. UV-VIS spectrum of compound 2 (a) in $\mathrm{MeOH}$, (b) in $\mathrm{MeOH}+\mathrm{NaOH}$
$J=7,5 \mathrm{~Hz}$ ) ppm. Using HMQC (Fig. 10) and DEPT with decouple, the first two protons were bound to one methylene carbon, while two other protons of each methyne where the carbon is bound to oxygen indicated substituted pirane proton. Based on the DEPT spectrum, there were six carbon signals lost at $\delta(\mathrm{ppm}) 157.58 ; 157.06 ; 156.78 ; 145.50 ; 132.04$; dan $100.48 \mathrm{ppm}$. The first four signals were from aromatic carbon substituted by oxygen, while the other two were from aromatic carbon substituted by carbon.

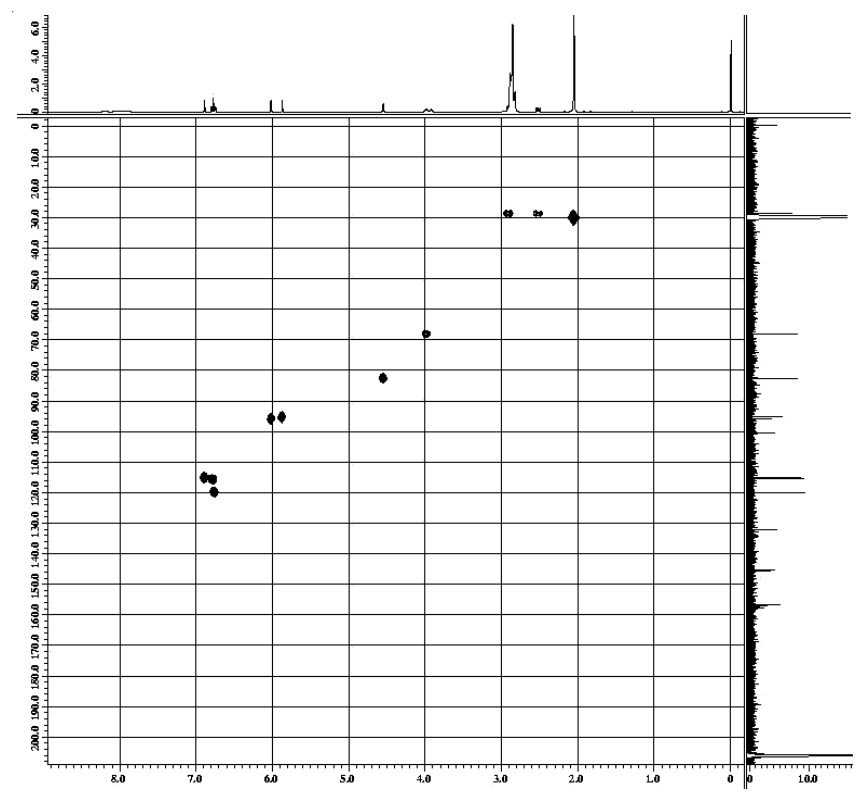

Fig. 10. HMQC spectrum of compound 2

Based on the HMBC spectrum of 2 (Fig. 11), which showed the correlation of protons with carbon in the molecule resulted the deduction that compound $\mathbf{2}$ is chatecin. This deduction is strengthen with COSY data (Fig. 12), the correlation of $\mathrm{H}-\mathrm{H}$ in 2, from $\delta$ (ppm): 2.465 to 2,865 and 3.92; 3.92 to 2.465 and 4.50 ; as well as 6.70 to 6.73 and 6.83 . The data comparison of ${ }^{1} \mathrm{H}$ and ${ }^{13} \mathrm{C}$ NMR of 2 with data in the literature $^{6}$ is shown in Table-2. Besides isolated from Artocarpus
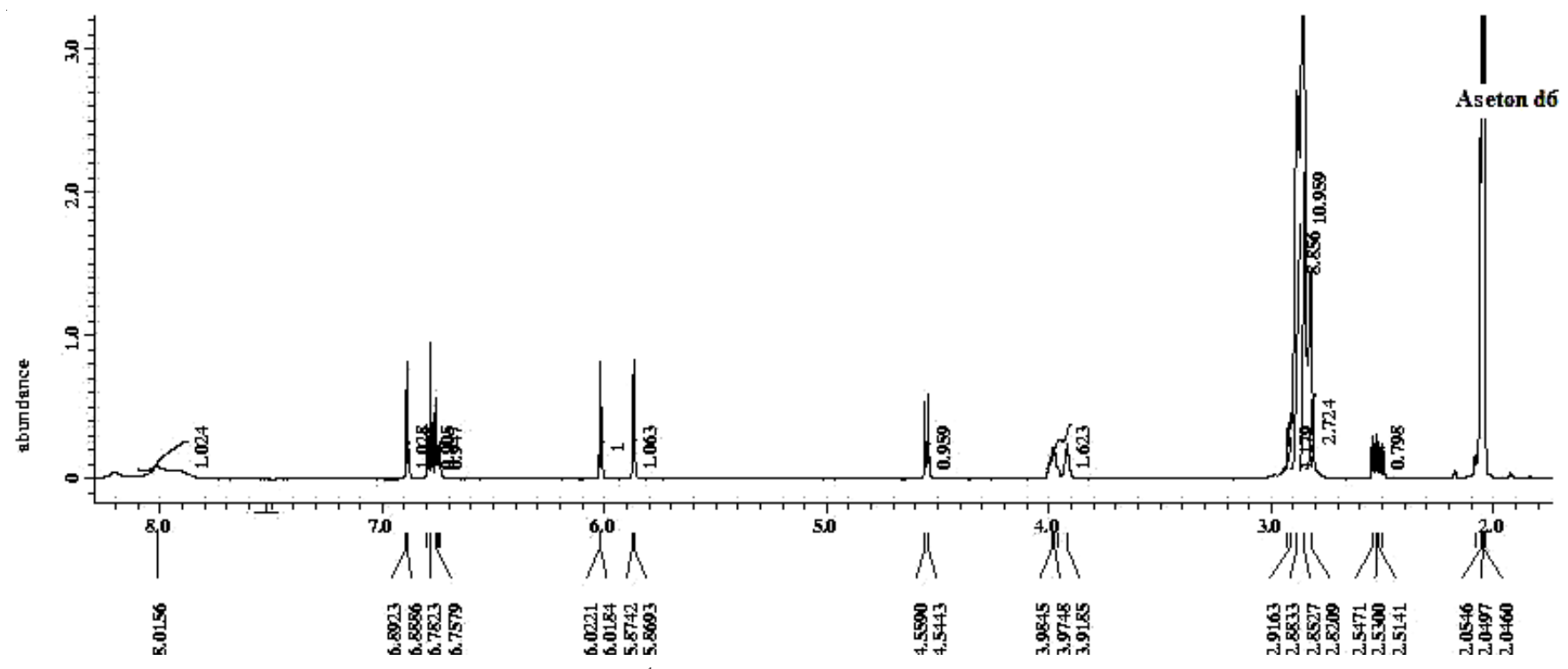


\begin{tabular}{|c|c|c|c|c|}
\hline \multicolumn{5}{|c|}{$\begin{array}{c}\text { TABLE-2 } \\
\text { COMPARISON OF }{ }^{1} \mathrm{H}-\text { AND }{ }^{13} \text { C-NMR DATA OF COMPOUND } 2 \text { AND CHATECIN }{ }^{6}\end{array}$} \\
\hline \multicolumn{2}{|c|}{ Chatecin $^{6}\left(\mathrm{CD}_{3} \mathrm{OD}\right), \delta(\mathrm{ppm})$} & $\mathrm{C}$ & \multicolumn{2}{|c|}{ Compound $\mathbf{2},\left(\right.$ acetone $\left.\mathrm{d}_{6}\right), \delta(\mathrm{ppm})$} \\
\hline${ }^{1} \mathrm{H}-\mathrm{NMR}$ & ${ }^{13} \mathrm{C}-\mathrm{NMR}$ & & ${ }^{1} \mathrm{H}-\mathrm{NMR}$ & ${ }^{13} \mathrm{C}-\mathrm{NMR}$ \\
\hline $4.56(1 \mathrm{H} . \mathrm{d} . J=7.5 \mathrm{~Hz})$ & 82.88 & 2 & $4.50(1 \mathrm{H} . \mathrm{d} . J=7.5 \mathrm{~Hz})$ & 82.59 \\
\hline 3.97 (1H. m) & 68.83 & 3 & 3.92 (1H. m) & 68.17 \\
\hline $2.49(1 \mathrm{H}$. dd. $J=8.0 ; 16.1 \mathrm{~Hz} .4 \beta)$ & 28.53 & 4 & $2.465(1 \mathrm{H} . \mathrm{dd} . J=8.5 ; 16.12 \mathrm{~Hz})$ & 28.71 \\
\hline \multirow[t]{3}{*}{$2.84(1 \mathrm{H}$. dd. $J=5.4 ; 16.1 \mathrm{~Hz} .4 \beta)$} & & & $2.865(1 \mathrm{H} . \mathrm{d} . \mathrm{j}=5.5 \mathrm{~Hz})$ & \\
\hline & 100.84 & $4 a$ & & 100.48 \\
\hline & 157.59 & 5 & & 157.06 \\
\hline \multirow[t]{2}{*}{$5.91(1 \mathrm{H} . \mathrm{d} . J=2.4 \mathrm{~Hz})$} & 96.31 & 6 & $5.96(1 \mathrm{H} . \mathrm{d} . J=1.85 \mathrm{~Hz})$ & 95.90 \\
\hline & 157.86 & 7 & & 157.658 \\
\hline \multirow[t]{3}{*}{$5.84(1 \mathrm{H}$. d. $J=2.4 \mathrm{~Hz})$} & 95.52 & 8 & $5.815(1 \mathrm{H} . \mathrm{d} . J=2.45 \mathrm{~Hz})$ & 95.25 \\
\hline & 156.93 & $8 a$ & & 156.78 \\
\hline & 132.25 & $1^{\prime}$ & & 132.04 \\
\hline \multirow[t]{3}{*}{$6.83(1 \mathrm{H}$. d. $J=2.0 \mathrm{~Hz})$} & 115.28 & $2^{\prime}$ & $6.83(1 \mathrm{H} . \mathrm{d} . J=1.85 \mathrm{~Hz})$ & 115.09 \\
\hline & 146.24 & $3^{\prime}$ & & 145.53 \\
\hline & 146.17 & $4^{\prime}$ & & 145.46 \\
\hline $6.75(1 \mathrm{H}$. d. $J=8.1 \mathrm{~Hz})$ & 116.10 & $5^{\prime}$ & $6.73(1 \mathrm{H}$. d. $J=8.6 \mathrm{~Hz})$ & 115.54 \\
\hline $6.71(1 \mathrm{H} . \mathrm{dd} . J=2.2 ; 8.2 \mathrm{~Hz})$ & 120.04 & $6^{\prime}$ & $6.70(1 \mathrm{H}$. dd. $J=1.8 ; 7.95 \mathrm{~Hz})$ & 119.92 \\
\hline
\end{tabular}

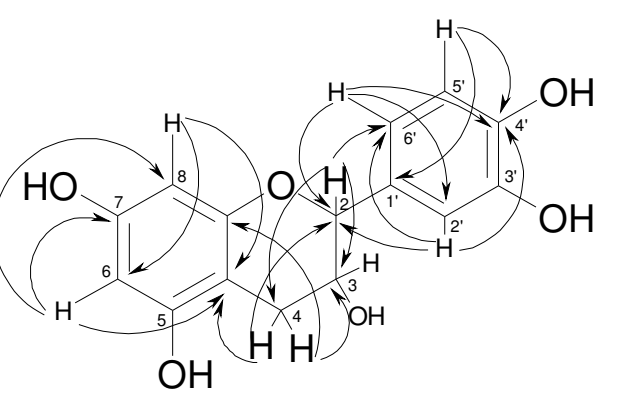

Fig. 11. Correlation of $\mathrm{H}-\mathrm{C}$ from $\mathrm{HMBC}$ data of compound 2

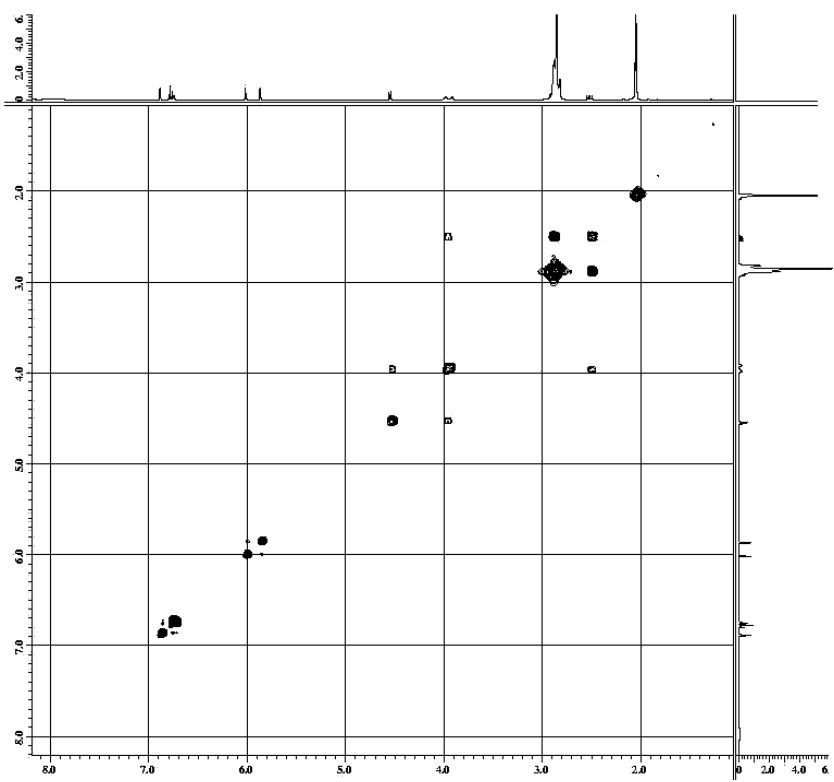

Fig. 12. Correlation of H-H from COSY spectrum of compound 2

plants, chatecin has also been isolated from other plants, such as from Acacia catechu ${ }^{9}$, Centaurea maculosa, Lam. ${ }^{10,11}$ and from Paullinia cupana var. sorbilis $)^{12}$.
Bioactivity assay: The cytotoxicity test using murine leukemia cancer cell P-388 showed that compounds $\mathbf{1}$ and 2 were not active with $\mathrm{IC}_{50}>100 \mu \mathrm{g} / \mathrm{mL}$.

\section{ACKNOWLEDGEMENTS}

The authors thanks The Directorate of Research and Community Services, Directorate General of Higher Education, The Ministry of National Education of Republic of Indonesia providing the fund for this project through National Strategic Research Grant Scheme 2011 with contract number of 411/ SP2H/PL/Dit.Litabmas/IV/2011, 14 April 2011.

\section{REFERENCES}

1. T. Suhartati, Yandri, J.F. Suwandi and S. Hadi, Eur. J. Sci. Res., 38, 643 (2009).

2. T. Suhartati, Yandri and S. Hadi, Int. J. Pure Appl. Chem., 4, 223 (2009).

3. T. Suhartati, Yandri, J.F. Suwandi and S. Hadi, Orient. J. Chem., 26, 825 (2010)

4. M.C. Alley, D.A. Scudiero, A. Monks, M.L. Hursey, M.J. Czerwinski, D.L. Fine, B.J. Abbott, J.G. Mayo, R.H. Shoemaker and M.R. Boyd, Cancer Res., 48, 589 (1988).

5. K.R. Markham, The Identification Methods of Flavanoid. ITB Publisher, Bandung, p. 41. (1988) (Indonesian).

6. S.A. Achmad, Murniana, S.S. Udjiana, N. Aimi, E.H. Hakim and L. Makmur, Proc. ITB, 30, 1 (1998) (Indonesian)

7. B.-N. Su, M. Cuendet, M.E. Hawthorne, L.B.S. Kardono, S. Riswan, H.H.S. Fong, R.G. Mehta, J.M. Pezzuto and A.D. Kinghorn, J. Nat. Prod., 65, 163 (2002).

8. S.E. Drewes and C.W. Taylor, Phytochemistry, 31, 1073 (1992).

9. M.A. Hye, M.A. Taher, M.Y. Ali, M.U. Ali and S. Zaman, J. Sci. Res., 1, 300 (2009)

10. A.C. Blair, S.J. Nissen, G.R. Brunk and R.A. Hufbauer, J. Chem. Ecol., 32, 2327 (2006).

11. B. Prithiviraj, L.G. Perry, D.V. Badri and J.M. Vivanco, New Phytol., 173, 852 (2007).

12. M. Kofink, M. Papagiannopoulos and R. Galensa, Eur. Food Res. Technol., 225, 569 (2007). 